\title{
Channel Strategy to Customer Satisfaction: Case of Traditional Retail Channel in Jakarta
}

\author{
Pantri Heriyati, Lita Tejaya
}

\begin{abstract}
Consumer's life style changes impact shifting trend in trade channel where is number of visits to traditional groceries continues to decline, while in contrary the visit to vegetable vendor and minimarts are increasing. Product Availability means product distributes well and ready at outlet. Product Affordability is extending to which perceived value of the product is greater than perceived cost at the outlet where customer buy its product. Customer satisfaction is an important strategy in maintaining customers, in most business include in retail chain. Declining growth on fast moving consumer product business especially beverages including bottled water and the increased of competition had brought many companies to re-look and invest on their distribution Strategy. Currently company mainly focuses on wholesalers, while a lot of opportunity to develop traditional retail. Company needs to really understand the strong reason traditional retail channel is important to be developed. Company must win the market competition thru product availability, product affordability, product quality and Product Variability. This research attempt to investigate the relationship of the Product Availability to Customer Satisfaction in water bottled business at Jakarta area and to provide insight on company maximizing product availability at the traditional retail channel. This study is using quantitative approach and data collection is buy distributing questionnaire to respondents of $A Q U A$, the biggest bottle water brand in Indonesia to consumer living in Greater Jakarta area. Sampling approach was convenient sampling technique. This researched managed to collect 400 valid responses. Data analysis and hypothesis testing was employed regression analysis with SPSS software. The finding found that product availability, Product affordability and Product quality significantly influence customer satisfaction of customer AQUA. Additional insight suggests product availability variable has the strongest influence for all Jakarta Area except West Jakarta on Customer Satisfaction than product affordability, product quality and product variability.
\end{abstract}

Keywords : Customer satisfaction; product availability; product affordability; product quality; product variability.

Revised Manuscript Received on September 22, 2019.

* Correspondence Author

Pantri Heriyati*, Business Management Program Management Department, BINUS Business School, Doctor of research in Management, Bina Nusantara University, Jakarta, Indonesia, pheriyati@binus.edu

Lita Tejaya, Business Management Program, Management Department, BINUS Business School Master Program, Bina Nusantara University, Jakarta, Indonesia, Itejaya@gmail.com

\section{INTRODUCTION}

The key strategies for Fast Moving Consumer Goods (FMCG) are properly manage the promotion, product portfolio management, small format channel product offering and consumer excitement. These strategies are according to Nielsen Company update 2017 - Indonesia Macro Economic and FMCG update; a weakening of consumer purchase or shifting priority. Factors that influencing industry retail Indonesia from 3 types of influencing factors. The first factor, positive influence; stable Gross Domestic Product (GDP) at $5 \%$ and high-level Consumer Price Index (PCI). The second factor, negative influence; Continues Price Increase (CPI) nearly around $4 \%$ every year. The third factor, other influencing factor; lower real income growth at minimum wage increase $8 \%$, Rational spending due to price pressure and the consciousness on the economy condition among upper SES consumer which is more selective on spending it also reported that annual inflation is picking up slightly at recent quarter but still around the government expectation $(4 \%+/-1 \%)$. FMCG by sector, there is Indication of slowing down shown across different sectors, while stable trend is only seen in the Household sector. FMCG trend is slightly lower than year of 2015, where the volume has been softening down in trend in the last 3 quarters (after Festive 2016) and the recent trend is still slightly negative. In June 2017 Beverage is $-3.1 \%$ versus 2016 [1].

Looking at detail by category, across the top 10 category, Biscuits, Cooking Oil and Liquid milk are still able to shows positive trend, while other categories trend is more challenging in both volume and value wise. Stable Gross Domestic Product (GDP) is based Indonesia Macro Economy indicator that shows Indonesia GDP Quartal-2 2017 is slightly increasing from previous quarter $(5.1 \%$ vs $5.0 \%)$, but still behind versus Quartal-2 last year (5.1\% vs $5.2 \%)$. From Nielson 2017 Report, life style also change with impact shifting trend in trade channel where is number of visits to traditional groceries continues to decline, while in contrary the visit to vegetable vendor and minimarts are increasing. Frequency of visiting (times in a month) in traditional groceries declined to 21 times per month in 2017 (from 23 in 2016) $(\mathrm{N}=14.348)$. The survey also found that in Nielsen Retail Audit in 2017 Top 10 Categories, indicating General Trade (only+4,2\% nominal growth) is more suffer compared to Modern Trade $(+7.5 \%$ nominal growth). Despite of General Trade or Traditional Trade is only $+4.2 \%$, this channel is still dominant as channel preference for household shopping. Since there is combined of shifting 
trend in the channel, weakening purchase power and FMCG volume is decreasing, so affordability might be one of the factors. Looking at the response to food price raising that buying less in total is common response across social economic status (SES), while buying discounted product rises only among SES category upper level of income. Further, consumer SES category lower income increasing in term of buy only the essentials we need/cut down on luxuries, buy less in total, actively look for and buy products on special/discounted prices, switch to cheaper brands, buy in bulk to get lower prices, and confirming that SES category lower income the most affected by food price rising. While SES higher income is $41 \%$ actively look for and buy products on special/discounted prices $(27 \%$ in 2016) and medium income is $36 \%$ buy less in total (27\% in 2016). In Mineral Water industry there are developing Small Pack Size (SPS) or also known as Water Bottled Category is still one of the most interesting businesses, where is $32.5 \%$ growth in volume [1].

Table I- Nielsen Retail Audit- Retail Trend \&Marketing Strategy 2017 Top 10 Categories

\begin{tabular}{|c|c|c|c|c|}
\hline No & Categories & $\begin{array}{c}\text { Contribution } \\
\text { (\%) }\end{array}$ & $\begin{array}{l}\text { Volume Growth } \\
\text { (\%) }\end{array}$ & $\begin{array}{c}\text { Value Growth } \\
(\%)\end{array}$ \\
\hline & Cigarette & 16.0 & 21.1 & 9.6 \\
\hline & Powder Milk & 5.9 & 17.9: & 14.8 \\
\hline & Alcoholic Beverages & 5.6 & 34.5 & 25.4 \\
\hline & Mineral Water (Bottled Water & 4.3 & 48.7 & 32.2 \\
\hline & Cooking Oil & 3.7 & 56.2 & 61.2 \\
\hline & Snacks & 3.6 & 33.3 & 26.4 \\
\hline & Biscuits & 3.5 & 28.2 & 21.8 \\
\hline & Skincare & 3.5 & 18.2. & 12.0 \\
\hline & Liquid Milk & 3.1 & 36.4 & 28.0 \\
\hline & Instant Noodles & 3.1 & 45.4 & 37.6 \\
\hline
\end{tabular}

Among brand in bottled water category, AQUA is the brand leader that dominate in the market and has reached the highest popular brand index, as shown in Table II below.

Table-II Popular Brand Index

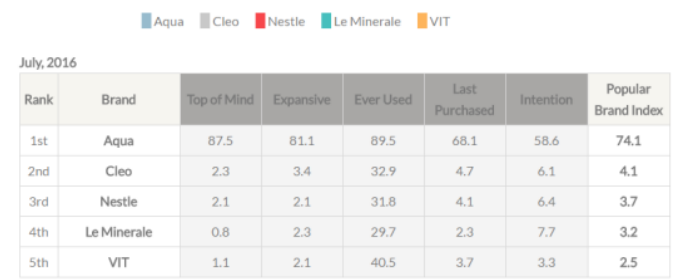

Source: Nusa Research W\&S Indonesia Digital Marketing Period 2016 [2]

To win the market competition, FMCG companies set the strategy to make their brands outstanding compared to competitions such as Multi-brand Strategy, Product Flanking, Brand Extensions, Building Product Lines, New Product Development, Product Life Cycle Strategy and Distribution Strategy. Among those strategies, FMCG is taking more seriously to distribution strategy. Distribution plays important roles since it will create different availability and visibility in order to win market competition. Distribution is merely about how product gets to customer; it is about availability and visibility to customer that impacts to customer satisfaction. In term of Channel, this research will focus on Traditional Retail
Channel since there is huge opportunities to develop this channel. In term of brand, this research focus on number one player in Bottled Water Category which is AQUA. As a market leader, AQUA has big opportunities to develop traditional retail channel [3]. Since, customers sometimes find it is difficult to buy this brand AQUA at traditional retail channel [4]. There is a lot opportunity to develop traditional retail channel since currently AQUA is mainly focus on main wholesalers [5].

Based on Based on Danone Registration Document Year 2016 [6], AQUA distribution model reflects two main approaches: Distribution aimed at major retail chain and distribution to traditional commercial sales points. This research will give the clear picture why traditional retail is important and to support business decision why AQUA needs to be present dominantly at traditional retail. So, this applied research will focus on Traditional Retail Channel.

Research Gap

Previous Research on factors affecting customer satisfaction in retail chain in Kenya: a case study of Nairobi Defense Force Canteen stated that retail chains with strong inventory management will effectively satisfy customers and cause them to prefer their services as compared to their competitors. This research involves 4 (four variables); Supply of product, Value of money, Quality improvement and Service quality, and result showing significantly affect to customer satisfaction. Customer satisfaction is an important strategy in maintaining customers, particularly those in retail chain. Customer satisfaction being an experience-based assessment made by customers and how far their expectations about the overall functionality of the services obtained, the study concludes that convenience stores offer a wide variety of products, but a limited number of choices within a particular product range. Therefore, availability of a wide variety of products is ranked higher as a store patronage attribute to store shoppers indicating expectations surrounding product assortment vary by retail chain [7]. Another previous research on Attractiveness Factors Influencing Shoppers' Satisfaction, Loyalty, and Word of Mouth (WOM): An Empirical Investigation of Saudi Arabia Shopping Malls stated that the attractiveness factors aesthetic, convenience and accessibility, product variety, entertainment, and service quality, had a positive effect on Saudi shopping mall shoppers. The most contributing factor to shopper's satisfaction was product variety [8]. Based on the notion, this research attempts to investigate and explore the relationship of customer satisfaction which include to examine the product availability, product affordability, product quality, Product Variability, and Product Variability which is combined and selected variables of those above two research, applied in traditional retail channel for the leading AQUA Brand in Jakarta.

\section{Research Problem}

Declining growth on FMCG business especially beverages including bottled water and the increased of competition had brought many companies to re-look and invest on their Distribution Strategy. Company must win the market competition thru product availability, product affordability, product quality and Product Variability. Company needs to really understand the strong reason to invest on traditional retail. 


\section{LITERATURE REVIEW}

\section{A. Channel Strategy}

The distribution channel strategy is divided into 2area is the management channel focusing on related activities with relationships between companies and intermediary and channel structure related to system development distribution [9]-[10]-[11]-[12]. Channel structure subdivided into two namely route to market which focuses on variations in the types of distribution channels that are company use and channel coverage which focuses on market coverage. Another definition of this channel of distribution is the one stated by The American Marketing Association which also states the number of institutions in the flow or flow of goods. The definition is: The distribution channel is an organizational structure within the company and outside the company consisting of agents, dealers, wholesalers and retailers, through a commodity, product or service being marketed [11]. A broader definition of distribution channels is a group of traders and company agents that combine the physical movement and name of a product to create uses for a particular market.

\section{B. Product Availability}

Distribution plays a vital role, primarily because it ultimately affects the sales turnover and profit margins of the organization. If the product cannot reach its chosen destination at the appropriate time, it can erode competitive advantage and customer retention [13]. Product characteristics are product elements that are considered important by consumers and are used as a basis for decision making [11].

Product Affordability is the extent to which the perceived value of the product is greater than its perceived cost at the outlet where the customer buys the product, linked to price impacted from each distribution channel, how flexible the price is, once the product goes to more layers of distribution channels from manufacturer until retailers. Far more challenging would be to model asymmetric information among channel members and how this may affect pricing contracts within a channel. This would require us to have access to a variety of contracts entered into by a firm under alternative levels of information asymmetry. Such data, however, are hard to obtain. But detailed data from a particular retailer (manufacturer) about the pricing contracts it enters into with different manufacturers (retailers) can be very useful in developing appropriate methodologies and obtaining insights on how channel members arrive at pricing contracts. Overall, the ratio of empirical to theoretical research on pricing across channels is low. This situation is being remedied as more data on both consumer choices across channels and retailer pricing become available and new empirical tools for analyzing retailer behavior are being developed. We hope these tools will provide greater insights about consumer behavior across channels, channel structure and relationships, and the behavior of channel participants in the near future [14].

\section{Product Quality}

Product Quality means the product can consistently meet the customer's requirement or expectation that could affect customer satisfaction. Consumer involvement, perceived quality, consumer satisfaction and purchase intentions should be used for segmentation purposes in order to identify homogeneous groups of consumers, target the most profitable segments, and implement effective marketing communication strategies [15]. The intention of the retailer is to improve his sales in order to stay in business and continue to offer satisfactory service to his customers. The retailer desires to retain existing customers, win new ones, and compete favorably with competitors within his retailing milieu. All these could be possible if the retailer operates a customer-oriented enterprise that meets all customer needs. Improved shopping environment, quality merchandise offered at conveniently located places at a reasonable price, as well as improved customer service quality are basic requirements for drawing customers to the store. Since all the lecturers who are also consumers of goods and services from the retail stores agreed that all the variables on merchandise display can influence impulse buying behavior, it could therefore be concluded that merchandise display is an important variable that can improve sales through impulse buying. Similarly, since all the respondents agreed that all the items listed in merchandise assortment are capable of influencing impulse buying, it could be concluded that merchandise assortment is an important element of retailing mix that retailers must maintain in order to meet the buying needs of their customers [16].

\section{Customer Satisfaction}

Consumer satisfaction has been extensively studied in marketing over the last few decades. However, marketing scholars have not yet agreed upon a generally accepted definition of satisfaction. Satisfaction is a summary affective response of varying intensity with a specific time point of determination and limited duration directed toward focal aspects of product acquisition and/or consumption [15].

\section{Distribution Strategy}

Distribution is one of the four aspects of marketing. A distributor is the middleman between the manufacturer and retailer. After a product is manufactured, it is typically shipped (and usually sold) to a distributor. The distributor then sells the product to retailers or customers. Nowadays, companies must achieve a high logistics performance combined with low costs and high quality. Companies are increasingly being forced to adapt their products to changing needs, promoting technological developments and fulfilling the high requirements placed on the delivery lead time and reliability, quality, and costs. Conventional, resource-oriented production planning and control is unable to meet these demands. A well-managed logistics system can provide the organization with a sustainable competitive advantage because an effective logistics management helps increasing customer satisfaction while maintaining delivery quality and decreasing costs. Only goal-oriented process planning can help in right logistics management [17]. 


\section{METHODOLOGY}

This research examines relationship of 4 (four) independent variables namely Product Availability; Product Affordability; Product Quality, and Product Variability to dependent variable namely customer satisfaction. The research model is illustrated in Figure I. below:

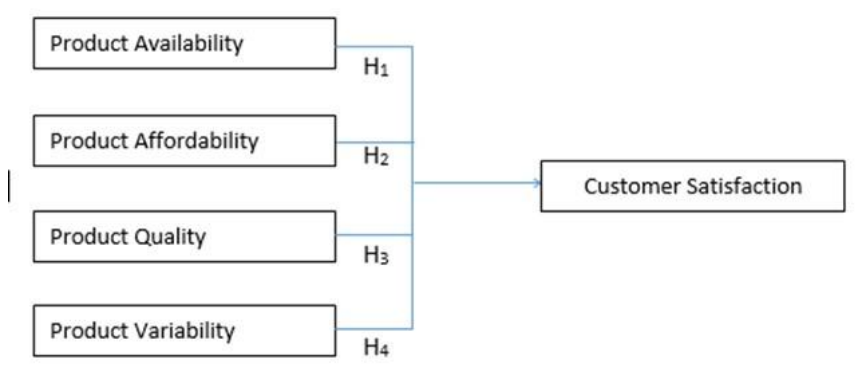

Fig. I. Research Model

Based on the model, this research developed four hypotheses as follow:

H1: Product availability has a significant influence to customer satisfactions.

$\mathrm{H} 2$ : Product affordability has a significant influence to customer satisfaction. relationship with customer satisfaction. customer satisfaction.

Based on BPS Data 2015 [18], Jakarta's Population is 4,459,586 and uses Slovin's sample size formula:

$$
\begin{aligned}
& n=\frac{N}{1+N e^{2}} \\
& \mathrm{n}=\frac{4.459 .586}{1+4.459 .586 *(0.05 * 0.05)}=400
\end{aligned}
$$

The population of this research is represented by the residents of Jakarta area within the age range of 25 to 54 years old, and who are in the productive age range or active working age and representing $45 \%$ of population of DKI Jakarta (BPS/Indonesian Statistic Bureau , 2015). Under the pre-determined 5\% margin of error and 95\% confidence level, the sample size needed is 400 . Due to the limited time provided to conduct the research, the researcher will use the convenience sampling method to collect the data by distributing offline and online questionnaires to 750 respondents according to criteria.

\section{RESULT AND DISCUSSION}

\section{A. Respondents Profile}

Out of 750 distributed questionnaires, this research managed to collect 400 valid responses. The respondent's profile is reported as follow: based on age, most respondents (78.75\%) were aged 25-39 years and dominated by male (54.50\%).
H3: Product quality has a significant influence to a

H4: Product variability has a significant influence to

Most respondents (84\%) are customers of bottled water and have been consuming for more than 2 years, where $36.25 \%$ of them buy bottled water more than 15 times per month. Brand AQUA is found as dominating brand Jakarta with $64 \%$ of Total consumption in Jakarta, more dominant from respondent from East Jakarta (67\%), and it is majority consuming AQUA 600ml (46.75\%).

\section{B. The Reliability and Validity Tests}

The value of Cronbach's Alpha on variable Product Availability is 0.764, Product Affordability is 0.624, Product Quality is 0.859 , Product Variability is 0.646 and Customer Satisfaction is 0.861 with a value greater than 0.6 . It is concluded that all variable are reliable. Using factor analysis, for product availability KMO Measure of Sampling Adequacy is 0.712 wand the p-value for Bartlett's Test of Sphericity is 0.000 , for product quality. The KMO Measure of Sampling Adequacy is 0.500 and the p-value for Bartlett's Test of Sphericity is 0.000 , for product variability KMO Measure of Sampling Adequacy is 0.544 and the p-value for Bartlett's Test of Sphericity is 0.000, for customer satisfaction The KMO Measure of Sampling Adequacy is 0.731 and the p-value for Bartlett's Test of Sphericity is 0.000 . All variables KMO values are above 0.6 and Bartlett's test are bellow 0.05 , therefore concluded to be valid.

\section{Hypotheses Testing}

Table III. shows the average value of Customer Satisfaction variable (Y) is equal to 12.1225 with a standard deviation of 2.14686. The average value of Product Availability variable (X1) is 15.7775 with a standard deviation of 2.03059. The average value of the Product Affordability (X2) variable is 7.2375 with a standard deviation of 1.55954 . The average value of Product Quality variable (X3) is 18.8975 with a standard deviation of 3.37795. The average value of Product Variability variable (X4) is 10.3225 with a standard deviation of 2.47564

Table-III. Descriptive Statistics

Descriptive Statistics

\begin{tabular}{|l|r|r|r|r|r|r|}
\hline & \multicolumn{1}{|c|}{ N } & Minimum & Maximum & \multicolumn{1}{c|}{ Mean } & Std. Deviation & Variance \\
\hline ProductAvailability & 400 & 8.00 & 20.00 & 15.7775 & 2.03059 & 4.123 \\
ProductAffordability & 400 & 4.00 & 10.00 & 7.2375 & 1.55954 & 2.432 \\
ProductQuality & 400 & 11.00 & 25.00 & 18.8975 & 3.37795 & 11.411 \\
ProductVariability & 400 & 4.00 & 15.00 & 10.3225 & 2.47564 & 6.129 \\
CustomerSatisfaction & 400 & 6.00 & 15.00 & 12.1225 & 2.14686 & 4.609 \\
Valid N (listwise) & 400 & & & & & \\
\hline
\end{tabular}

To test the hypotheses, Multiple regression analysis is conducted using SPSS software version 20.0. It test the influence of Product Availability (X1), Product Affordability (X2), Product Quality (X3), and Product Variability (X4) as independent variables to Customer Satisfaction (Y) as the dependent variable.

The regression model is as follows. $\mathrm{Y}=\beta 0+\beta 1 \mathrm{X} 1+\beta 2 \mathrm{X} 2+\beta 3 \mathrm{X} 3+\beta 4 \mathrm{X} 4$ 
Tabel-IV. Multiple Regression Coefficients Coefficients $^{\text {a }}$

\begin{tabular}{|c|c|c|c|c|c|c|}
\hline \multirow[b]{2}{*}{ Model } & & \multicolumn{2}{|c|}{ Unstandardized Coefficients } & \multirow{2}{*}{$\begin{array}{c}\begin{array}{c}\text { Standardized } \\
\text { Coefficients }\end{array} \\
\text { Beta }\end{array}$} & \multirow[b]{2}{*}{$t$} & \multirow[b]{2}{*}{ Sig. } \\
\hline & & $B$ & Std. Error & & & \\
\hline \multirow[t]{5}{*}{1} & (Constant) & 1.121 & .743 & & 1.509 & .132 \\
\hline & ProductAvailability & .239 & .041 & .229 & 5.876 & .000 \\
\hline & ProductAffordability & .145 & .063 & .106 & 2.292 & .022 \\
\hline & ProductQuality & .238 & .032 & .374 & 7.326 & .000 \\
\hline & ProductVariability & .162 & .048 & .187 & 3.363 & .001 \\
\hline
\end{tabular}

Dependent Variable: Customersatisfaction

Table IV shows the Coefficient table, the equation of the multiple linear regression model and is formulated as follows.

$$
Y=1.121+0.239 X_{1}+0.145 X_{2}+0.238 X_{3}+0.162 X_{4}
$$

where $\mathrm{X} 1=$ Product Availability, $\mathrm{X} 2=$ Product

Affordability, X3 = Product Quality, X4 = Product

Variability, $\mathrm{Y}=$ Customer Satisfaction

Based on the regression equation above, it can be explained that Product Availability, Product Affordability, Product Quality and Product Variability all have a positive relationship with Customer Satisfaction since the coefficients are positive. Since the product availability variable has the highest $\beta(0.239)$, it has the greatest influence on Customer Satisfaction than product affordability, product quality, and product variability. The lowest $\beta$ is product affordability (0.145).

The p-value for Product Availability variable based on the regression table is smaller than 0.05 which is 0.000 . Therefore, H1 is supported. Product Affordability variable has 0.022 as its p-value which is smaller than 0.05 , so, it is concluded that $\mathrm{H} 2$ is supported. The p-value for Product Quality variable based on the regression table is smaller than 0.05 which is 0.000 . Therefore, $\mathrm{H} 3$ is supported. The $\mathrm{p}$-value for Product Variability variable is 0.001 which is smaller than alpha level of 0.05 , so $\mathrm{H} 4$ is supported.

Table-V. Regression

\begin{tabular}{|c|c|c|c|c|c|c|}
\hline \multicolumn{7}{|c|}{ ANOVA $^{a}$} \\
\hline \multicolumn{2}{|c|}{ Model } & $\begin{array}{l}\text { Sum of } \\
\text { Squares }\end{array}$ & df & Mean Square & $\mathrm{F}$ & Sig. \\
\hline \multirow[t]{3}{*}{1} & Regression & 782.015 & 4 & 195.504 & 73.061 & $.000^{b}$ \\
\hline & Residual & 1056.983 & 395 & 2.676 & & \\
\hline & Total & 1838.998 & 399 & & & \\
\hline
\end{tabular}

Table V. shows that the p-value based on the ANOVA table is 0.000 which is less than $\alpha=0.05$, so it can be concluded that Product Availability (X1), Product Affordability (X2), Product Quality (X3) and Product Variability (X4) all have a positive significant relationship with Customer Satisfaction (Y).Coefficient of determination (R2) is used to measure how well the regression line corresponds to the actual data (goodness of fit). This coefficient of determination measures the percentage of total variation of the dependent variable described by the independent variable(s) in the regression line.
Table-VI. Model Summary R-squared

Model Summary

\begin{tabular}{|l|r|r|c|c|}
\hline Model & $R$ & R Square & $\begin{array}{c}\text { Adjusted R } \\
\text { Square }\end{array}$ & $\begin{array}{c}\text { Std. Error of } \\
\text { the Estimate }\end{array}$ \\
\hline 1 & $.654^{\mathrm{a}}$ & .428 & .422 & 1.63215 \\
\hline
\end{tabular}
a. Predictors: (Constant), ProductVariability,
ProductAvailability, ProductAffordability, ProductQuality

Table VI. shows that coefficient of determination or R-squared is 0.428 means that the contribution of Product Availability (X1), Product Affordability (X2), Product Quality (Q3) and Product Variability (X4) variables together can explain the Customer Satisfaction (Y) variable to the extent of $42.8 \%$, while the rest of $57.2 \%$ is explained by variables uncovered by this study.

\section{Demographic Analysis}

ANOVA is employed for additional demographic analysis using age and gender to understand how each variable works on each age range, to help the company in designing its activities in the traditional retail channel.

Table-VII. Age Analysis based on Coefficients' P-value

\begin{tabular}{||c||l||l||l||l||}
\hline \multicolumn{1}{|c||}{ Age } & $\begin{array}{c}\text { Product } \\
\text { Availability }\end{array}$ & $\begin{array}{c}\text { Product } \\
\text { Affordability }\end{array}$ & Product Quality & $\begin{array}{c}\text { Product } \\
\text { Variability }\end{array}$ \\
\hline \hline $25-29$ years old & .000 & .231 & .000 & .001 \\
\hline \hline $30-39$ years old & .180 & .917 & .442 & .000 \\
\hline \hline $40-49$ years old & .724 & .000 & .000 & .066 \\
\hline
\end{tabular}

Table VII shows that Product Availability (X1) is less than 0.05 for age 25-29 years old, which means H1 is supported. Product Affordability (X2) is less than 0.05 for age 40-49 years old, which means H2 is supported. Product Quality (X3) is less than 0.05 for age 25-29 years old and 40-49 years old, which means H3 is supported. Product Variability (X4) is less than 0.05 for age 25-29 years old and 30-39 years old, which means $\mathrm{H} 4$ is supported.

Table-VIII. Gender Analysis based on Coefficients' P-value

\begin{tabular}{||l||l||l||l||l||}
\hline \multicolumn{1}{|c||}{ Gender } & $\begin{array}{c}\text { Product } \\
\text { Availability }\end{array}$ & $\begin{array}{c}\text { Product } \\
\text { Affordability }\end{array}$ & Product Quality & $\begin{array}{c}\text { Product } \\
\text { Variability }\end{array}$ \\
\hline \hline Male & .000 & .001 & .000 & .088 \\
\hline \hline Female & .008 & .320 & .000 & .000 \\
\hline
\end{tabular}

Table VIII. shows that Product Availability (X1) is less than 0.05 for male and female, which means $\mathrm{H} 1$ is supported. Product Affordability (X2) is less than 0.05 for male, which means H2 is supported. Product Quality (X3) is less than 0.05 for male and female, which means H3 is supported. Product Variability (X4) is less than 0.05 for female, which means H4 is supported.

\section{CONCLUSION}

Based on data, the survey has been responded by majority respondents at the age of 25-44 years old, living in Jakarta, men, have been using AQUA more than 24 months, and more than 15 times buy AQUA per month (36.25\%), dominating by respondents is AQUA $600 \mathrm{ml}$ customer $(46.75 \%)$, has the result of the research as following: 
- Product availability has a positive significant relationship with customer satisfaction

- Product affordability has a positive significant relationship with customer satisfaction

- Product quality has a positive significant relationship with customer satisfaction

- Product variability a has positive significant relationship with customer satisfaction.

Based on multiple regression by area, the product availability variable has the highest $\beta$ for all Jakarta Area except West Jakarta (the highest $\beta$ is quality) means product availability has the greatest influence on Customer Satisfaction than product affordability, product quality and product variability. For age analysis, there is no significant positive relationship product affordability and product variability with customer satisfaction in age 25-29-years old. While in age 30-39 years oldthere is no significant positive relationship product affordability and product quality with customer satisfaction. For gender analysis, Male, product availability and product quality are significant positive with customer satisfaction while for female, product affordability has no positive relationship with customer satisfaction. From One-Way ANOVA result shows that West Jakarta region is the lowest in customer satisfaction, while the highest is in East Jakarta. Based on the result, Product Availability, Product Affordability, Product Quality and Product Variability are the factors need to be focused on and to be improved since the mean of respondents respond still below Likert scale 4 (Agree):

1. Product Availability

I can buy AQUA maximum 3 boxes at traditional retail Product Affordability

2. Product Quality

AQUA packaging at traditional retail has no dust

$A Q U A$ water color at traditional retail is clear

AQUA bottle at traditional retail is not dented

AQUA at traditional retail has good boxes

AQUA quality at traditional retail is good

3. Product Variability

AQUA has many bottles size variants at traditional retail

AQUA has many cartons size variants traditional retail

AQUA has many designs at traditional retail

This study shows that to ensure the achievement of AQUA customer satisfaction, it is essential to improve the Product Availability, Product Quality and Product Variability of the company. AQUA needs to strengthen these components to win the competitive market. AQUAcannot avoid new players entering into this water bottle business or market. Therefore, to help AQUA to stay competitive against the existing player and new comers in the market, AQUA should focus on improving these 3 components:

1. Product Availability. AQUA needs to ensure its availability at traditional retail and display it properly so it can be easily seen by customers. Company need to put investment on how to cover more traditional retail and more frequent visiting the traditional retail thru better route to market. Company need to set new rule for quantity of order for single traditional retail outlet, minimal 4 boxes per drop size.

2. Product Quality. AQUA quality is one the concern of customer. Company needs to ensure the quality of the product from packaging, bottle until water itself from the manufacturer until display at the traditional retail. The quality of outer packaging and inner packaging needs to be secured to guarantee the good quality. Campaign on AQUA QUALITY commitment will focus on this. Salesman visit the traditional retail regularly to ensure the quality and educate the traditional retail for better product handling. Salesman needs to bring the sales cleaning tools to clean up the display stock and educate the outlet on how to handle the product.

3. Product Variability. Customer needs to have more choices in variant of bottle size, carton size and design of the bottles. Innovation is key to have better product variability to fulfill customer needs. Each single segment or class customer has their own preferences, they need to have more choices such as for school - preferred 330ml, for family at home - preferred gallon. Even content per box is different request from different customer. Salesman target has to set to have minimal 3 variant of AQUA selling in every single outlet.Hence, by focusing on the above factors, AQUA should be able to maintain its position as the market leader in water category and continue to maintain high customer satisfaction in the future.

\section{REFERENCES}

1. Nielsen Company (2017, June 16 ). Indonesia Macroeconomy and FMCG Updates. Available: https://www.nielsen.com/us/en/insights/reports/2018.html?q=*\&q_10 =listing \&q1=Report\&x1=contenttypetag \&pageFacets=Report\&defaul tSearchText=\&sp q 4=Category:FMCG\%20and\%20Retail\&sp x 4 $=$ tags $\& \_=1518912000000 \& \times 3=$ categorytag \&q3=FMCG $\% 20$ and $\% 20$ $\underline{\text { Retail }}$

2. Nusa Research (2016, October 16). W\&S Indonesia Digital Marketing Period July 2016 - Popular Brand Index. Available: http://nusaresearch.com/pbi/zoom.php?ID=98\&IDbrand=25\&IDcateg ory $=2$

3. Rohmah (2016, May 16 ). Aqua-Integrated Marketing Communication 2. https://www.slideshare.net/FitriaNurulRohmah/proposal-aqua-tugas-i $\mathrm{mc}$

4. Angriawan (2015, August 7). Scarcity of Bottled Water Product. Available:

http://www.madiunpos.com/2015/10/16/distribusi-air-minum-solo-du h-air-minum-dalam-kemasan-di-solo-langka-652449

5. Jacky (2012, April 10 ). Strategic Management SWOT Analysis of PT. Aqua Danone. Available https://1nfot3ch.wordpress.com/2012/10/02/manajemen-strategi-anali sis-swot-pada-pt-aqua-danone/

6. Danone (2016, September 10). Danone Registration Document 2016 Available:

http://wikirate.s3.amazonaws.com/files/3153906/13569365.pdf

7. Owuorand, V.A, Waiganjo E., "Factors Affecting Customer Satisfaction in Retail Chains in Kenya: a case study of Nairobi Defense Forces Canteen" International Journal of Business \& Law Research, 2(4), 2014, pp 73-87.

8. Ahmad. (2012)," Attractiveness Factors Influencing Shoppers' Satisfaction, Loyalty, and Word of Mouth: An Empirical Investigation of Saudi Arabia Shopping Malls," International Journal of Business Administration, 3(6), 2012, pp 101-112.

9. Jindal, R. P., Reinartz, W., Kraft., M., and Hoyer, W.D, (2007), "Determinants of the variety of routes to market," International Journal of Research in Marketing, 24,2007, pp 17-29.

10. Mullins, J.W., Walker, O.C., Larreche, J.C., and Boyd, H.P. (2005), "Marketing Management: A Strategic Decision-Making Approach," 5th ed, New York: McGraw-Hill, 2005 
11. Kotler., P., (1997), "Marketing Management: Analysis, Planning, Implementation, and Control, “ 9th ed., Prentice Hall International Editions, New Jersey, 1997.

12. Stern, L.W., Ansary, A.I., and Brown, J.(1989), Management in Marketing Channels, New Jersey: Prentice Hall, 1989

13. Yeboah A, Owusu A, Boakye S, Mensah S.O., "Effective distribution management, a pre-requisite for retail operations: a case of Paku Trading, " European Journal of Business and Innovation Research, 1 (3), 2013, pp 28-44.

14. Sudhir K, Datta S., "Pricing in Marketing Channel," Yale School of Management, 2010, Unplublished.

15. Tsiotsou, "The role of perceived product quality and overall satisfaction on purchase intention," International Journal of Consumer Studies, 30, 2006, pp 207-217.

16. Asuquo E.E., Igbongidi P.B., "Retail Store Merchandise Assortment and Display and their Influence on Consumer Impulse Buying Behaviour in North West Nigeri," British Journal of Marketing Studies, 3 (5), 2015, pp 49-60

17. Pisz, "Controlling of Logistic Projects," Total Logistic Management, 4, 2011, pp 107-123.

18. Badan Pusat Statistik/ BPS/Indonesia Statistical Bureau (2015, June 14 ). Available: http://www.pusdatin.kemkes.go.id/resources/download/profil/PROFI L_KES_PROVINSI_2012/11\%20Profil_Kes.Prov.DKIJakarta.pdf

\section{AUTHORS PROFILE}

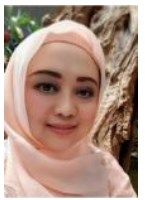

Pantri Heriyati currently serves as Leader of Centre fo Business and Social Empowerment at Bina Nusantara University, Jakarta. She earned her Doctorate degree in Management from University of Indonesia, and Master's degree in Commerce from Wollongong University, Australia. She served in education sector for more than 15 years with a strong industrial background in multinational companies for more than 10 years. Her research interest is in the field of corporate marketing strategy and consumer behavior. She was also a member of the American Marketing Association and Academy of Management in year 2010-2015. Her work has been published in various reputable journals and she is also listed as a referee committee for several national academic journals. Among her publication are: Customer Loyalty and Its Influence on Price War Intensity in the Indonesian Lighting Industry. International Journal of Engineering Technology, 7(3.30), 2018, 555-560

DOI 10.14419/ijet.v7i3.30.18430; Venture Legitimacy and Story Telling in Social Enterprise. Journal Small Enterprise Research, Routlege Taylor \& Francis. https://doi.org/10.1080/13215906.2019.1570318; How Price Perception and Satisfaction Influence Online Repurchase Intention. Pertanika Journal of Social Science. \& Humanities. 26 (T): 9 - 17, 2018

i Consumer Innovativeness and Shopping Style: A Study on Consumer Shopping Behavior in the Greater Jakarta Area. Vol 3, 2015, ISSN: 1993-5250, pp 215-220, International Business Management, Emerald Insight

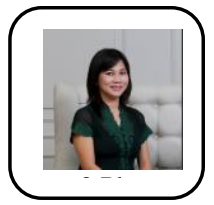

Lita Tejaya was graduated from Master Program in Business Management, Binus Business School, Bina Nusantara University, Jakarta, Indonesia. Currently she holds position as Sales Director, Sinarmas Consumer Products, Jakarta, Indonesia and was former Sales Director, Danone Water Indonesia, Jakarta, Indonesia 